\title{
CEO Compensation And Firm Value
}

Abdallah M. Dah, Ph.D., Lebanese American University - Beirut Campus, Lebanon Salaheddine S. Abosedra, Ph.D., Lebanese American University - Beirut Campus, Lebanon Ghida F. Matar, Lebanese American University - Beirut Campus, Lebanon

\begin{abstract}
This paper examines the effect of CEO equity-based compensation (EBC) on firm value. In particular, we study the interaction between EBC and the percentage of independent directors as well as the interaction between EBC and managerial entrenchment. Our findings suggest a positive relation between firms' value and EBC. Further, we show that the percentage of independent directors has a positive impact on the marginal effect of EBC on firm value.
\end{abstract}

Keywords: CEO Equity-based Compensation; Firm Value; Independent Directors

\section{INTRODUCTION}

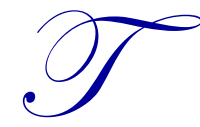

he agency problem stems from the fact that managers and stockholders might have conflicting goals within the same firm. Whether rewarding managers positively affects their performance and thus the firm value or not has been a controversial issue on which several academic research have addressed.

Previous research on the effect of equity-based compensation (EBC) on firm value reached different conclusions. Results of previous scholarly work ranged from a positive relation to no significant relation -with the firm value being proxied by Tobin's $Q$. This paper, thus, investigates whether equity-based compensation will help to align management and shareholders' objectives. Our empirical results suggest that equity-based compensation does have a direct and indirect positive effect on firm value. Research findings also show that the marginal negative effect of managerial entrenchment on firm value will be reduced for firms that are characterized with high EBC. Furthermore, an increase in the percentage of independent directors increases the positive marginal effect of EBC on shareholders wealth.

Using an interaction variable between equity-based compensation (EBC) and the percentage of independent directors suggests that when CEO's are rewarded through equity-based compensation, the marginal impact of this $\mathrm{EBC}$ on firm value increases.

\section{REVIEW OF LITERATURE AND RESEARCH HYPOTHESES}

The performance of any firm is affected by many important managerial decisions of which how to price goods, which markets to enter, and how to face competition. The quality of such decisions doesn't depend merely on the managers' ability but also on the incentives they have to create value for stockholders as seen by Byrd, Parrino, and Pritsch (1998).

The fact that managers and stockholders might have conflicting goals gives rise to the agency problem. Byrd, Parrino, and Pritsch (1998) document the four problems arise because of the agency problem: the effort, horizon, differential risk preference, and asset use problems. They state that an effective compensation contract will be able to provide managers with incentives to make decisions that the stockholders will want and thus minimize the conflict between the two parties. According to Hallak (2011), the general agency theory suggests that the manager should be provided with equity-based compensation to align his interests with those of the firm owners. Equitybased compensation types include stock options, warrants, employee shares, and others according to Hojen (2007) 
and are viewed as a means to motivate managers to satisfy stockholders interests since it results in a share of ownership between both.

Supporters of the use of these equity-based grants as an incentive tool argue that these grants will result in increased firm performance while opponents argue that the positive effects of these programs are highly over-stated and their costs are higher than the achieved results.

As of the mid-1990s, one-third of total (U.S.) Chief Executive Officer (CEO) compensation was in the form of stock option awards, up from one fifth during the 1980s according to Hall and Liebman (1998) and Murphy (1998). Also, upon examining 544 proxy statements for firms with CEOs listed in the 1994 Forbes compensation survey, $66.5 \%$ of these CEO's were found to receive incentives in the form of option grants during the year 1993 according to Byrd, Parrino, and Pritsch. In addition, large firms rely more on CEO stock-option awards compared with cash compensation based on a study made by Yermack (1995). Thus, there is a wide use of equity-based incentive compensation in the US firms-with two kinds of audience: supporters and opponents. This explains why for years researchers have been interested in studying the general agency theory. Thus, many empirical studies were published in this manner-but were of contradictory results.

Among the studies whose results support the general agency theory we find the study of Mehran (1995) who documents a positive relationship between the percentage of equity-based compensation the manager receives and the performance at manufacturing firms. Similarly, using a large sample of U.S. firms over the 1992-97 period, Bryan, Hwang, and Lilien (2000) obtains results that provide strong support for the predictions of optimal CEO stock option, restricted stock awards, and their direct effect on firm performance. McConnell and Servaes (1990) also document a positive relationship between managerial stock ownership (and thus stock-based compensation) and firm performance; even though the performance wasn't monotonic. Smith (1990) and Kaplan (1989) also report direct evidence of the incentive effects of large stockholdings on operational efficiency. Defusco, Johnson, and Zohn (1990) report an increase in shareholder wealth surrounding the announcement of an executive stock option plan. Milkovich and Gerhart (1990) use longitudinal data on about 14,000 top and middle-level managers and 200 organizations and found that contingent pay in the form of equity-based compensation was positively associated with firm performance enhancement. Hillegeist and Penalva (2003) perform tests separately for the top-5 executives and all other employees. The relation between firm performance, proxied by abnormal future returns, Tobin Q, and future return on firm's assets, and the level of performance used, the authors provide an evidence of a positive and significant relation between better firm performance and option incentives . This conclusion holds for executives and employees.

On the other hand, Warren Buffet, one of the leading opponents of this view, believes "Although options can be an appropriate, and even ideal, way to compensate and motivate top managers, they are more often wildly capricious in their distribution of rewards, inefficient as motivators, and inordinately expensive for shareholder". Various studies were performed that support this point of view. Yermack (1995) document a negative association between incentive-intensity and the firm's investment opportunities and performance. Hojen (2007) finds that no significant effects from the equity-based compensation contracts in the short-term perspective exist. The same result is reached when studying the effects of the equity-based compensation contracts in the long-term perspective except that abnormal returns were noted in the fourth and twelfth months. Hojen (2007) concludes that no significant difference in operational performance (measured by ROA, ROE and Tobin's Q) was noted comparing pre-adoption and post-adoption of the compensation plan. Similarly, the study of Jensen and Murphy (1990) proves that there is a lack of strong pay-for-performance incentives for CEOs and thus performance-related compensations of all types have no positive effect on the actual performance. They report that the manager's share of increases in the firm value averaged around 3\%. In later work, Hall and Liebman (1998) find that by more exhaustively incorporating the value of executive stock options into the calculations, this pecentage increases, but remains relatively low. Equally, Kedia and Mozumdar (2002) find that the use of options is successful in retaining employees and creating value as reflected by positive abnormal returns. Furthermore, the author provides evidence on value creation through the use of stock option to deal with firm's financial constraints. However, the use of stock options was not as successful in high gross firms. 
The review of the above studies shows that no empirical consensus on the form of the relationship (whether positive or negative) exists between equity-based compensation for managers and the firm-value and managerial performance. This lack of consensus creates the foundation of our research as we shall attempt to revisit this issue to explore further the reality of this relationship which will enable us to contribute to this debate.

Does a relationship actually exist between CEO equity-based compensation (EBC) and firm value? This research will try to figure out whether awarding CEO's with equity-based compensation increases Tobin's Q (firm value) as concluded by some researchers or not-as reached by others.

$\mathbf{H}_{\mathbf{0 1}} \quad$ There is no relationship between CEO equity based compensation and firm-value

Another question that will be addressed in this research is whether a change in the percentage of independent directors will cause a change in the marginal effect of $\mathrm{EBC}$ on firm value or not. When this percentage increases beyond a certain (average) level, does the effect of EBC on firm-value change? If it does, does it become weaker or stronger?

$\mathbf{H}_{\mathbf{0 2}}$ : The percentage of independent directors does not cause a change in the marginal effect of EBC on firm value.

Finally, we will find out whether the level of entrenchment and its marginal impact on firm performance will be affected by EBC of CEO.

\section{DATA \& DESCRIPTIVES}

This paper utilizes data from three major databases, namely, CompuStat that provides information on firm's financials, IRRC data base which provides information related to external measures of governance, and Execucomp database that furnishes information on CEO compensation package and duality. The data collected covers the period from 1994 till 2009. The definition of the variables used in this research paper is as follows:

Tobin's Q: (MVE + PS + BVINV + LTDEBT + CL - CA)/TA

where MVE is the value of common stocks at the end of the year. BVINV is the book value of the inventory. LTDEBT refers to the book value of the long-term debt. CL stands for current liabilities while CA stands for current assets. TA is the book value of the Total Assets in the firm.

Sales-to-Assets (sales_at): The ratio of the firms' sales to assets. ROA1: The ratio of EBITDA/Assets. EBITDA is a shortcut for Earnings Before Interest, Tax, Depreciation and Amortization. EBC: The amount paid to the firms' CEO as equity-based compensation during the current year. RDExp: Research and Development expenses for the previous year. E: Level of Entrenchment. It takes a value between 0 and 6 . Board Size: The number of directors serving on the board. \% of Independent Directors: The percentage of external directors serving on the board. CEO Chair: A dummy states whether the CEO is also a chair. It takes a value of 1 if CEO is also a chair and 0 otherwise. IndepDum: $\%$ of independent directors dummy that takes a value of 1 if the $\%$ is more than the sample mean value and 0 otherwise. EBC IndepDum: Interaction variable which is the product of EBC and \% of independent variables dummy. EBCDumEIndex: Interaction variable which is the product of EBC Dummy and EIndex.

\section{EMPIRICAL FINDINGS}

The first model simply attempts to answer the first research question on the nature of relationship between shareholders wealth, proxied by Tobin Q, and CEO equity based compensation. Table 1 summarizes the results of Panel data with industry fixed effect. Explanatory variables include research and development, sales-to-assets ratio, return on assets, equity-based compensation, E-index, percentage of independent directors, board size, and year dummy variables which are not reported for space convenience. A significant negative relation at $1 \%$ level of 
significance exists between Tobin's Q and sales-to-assets ratio, the E-Index, and percentage of independent directors. A significant negative relation at 5\% level of significance also exists between Tobin's Q and board size. On the other hand, a positive and significant relation at less than 1\% level of significance exists between Tobin's Q and spending on research and development, return on assets, and CEO equity-based compensation. Thus, our findings suggest a direct relation between CEO equity based compensation and firm value. We can thus reject Hypothesis $\mathrm{H}_{01}$.

Table 1

Panel Data with Industry Fixed Effect

\begin{tabular}{|c|c|c|}
\hline \multicolumn{3}{|c|}{ 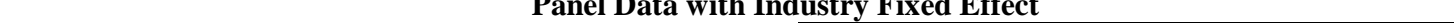 } \\
\hline & \multicolumn{2}{|c|}{ Unstandardized Coefficients } \\
\hline & B & Sig. \\
\hline (Constant) & 1.319 & .000 \\
\hline RDexp & 8.764 & .000 \\
\hline sales_at & -0.190 & .000 \\
\hline ROA1 & 6.653 & .000 \\
\hline EBC & $2.124 \mathrm{E}-5$ & .000 \\
\hline $\mathrm{E}$ & -0.119 & .000 \\
\hline Percentage_Independent & -0.008 & .000 \\
\hline BoardSize & -0.090 & 0.03 \\
\hline
\end{tabular}

Note. Dependent Variable: Tobin Q. Year dummy variables are included but not reported.

While keeping the same set of control variables, Table 2 represents the Panel data results with industry fixed effect, of the interaction between EBC and the percentage of independent directors dummy. Sales-to-assets, managerial entrenchment, board size, and percentage of independent directors have maintained their marginal, negative and significant impact on firm value. On the other hand, investment in research and development, rate of return on assets and, and EBC kept their significant and positive relation with firm value. From Table 6, we note that the coefficient of the interaction variable is positive showing that when the percentage of independent directors is above the sample mean, the marginal effect of CEO equity based compensation (EBC) on firm value increases. We may, therefore, conclude that the percentage of independent directors does cause a positive change in the marginal effect of EBC on firm value.

Table 2

Panel Data with Industry Fixed Effect

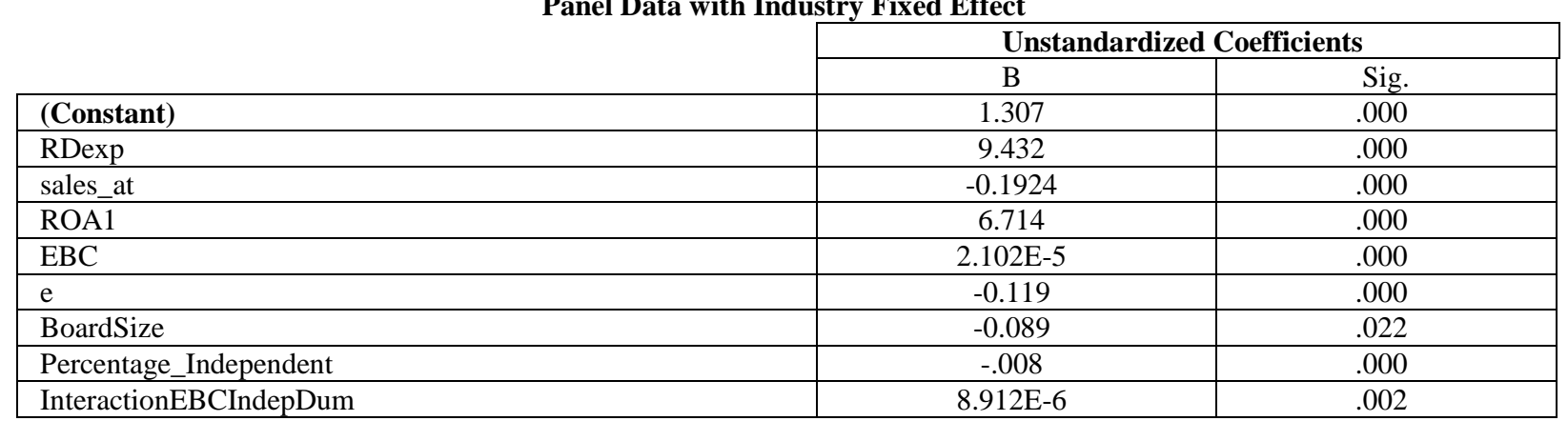

Note. Dependent Variable: Tobin Q. Year dummy variables are included but not reported.

\section{CONCLUDING REMARK}

Efforts to moderate the negative impact of agency problems on shareholders wealth has always been a major challenge for policy makers, practitioners, and academicians. One way to mitigate this problem is to design and provide equity-based compensation (EBC) packages to top management. This is expected to improve managers' performance and thus increase the firm value. Whether this strategy successfully aligns management and shareholders objectives or not is still controversial. This paper studies the marginal effect of EBC on shareholders wealth, and whether or not this marginal effect changeswith the percentage of independent directors 
Our findings support the existence of a relationship between CEO equity-based compensation (EBC) and firm performance. Empirical evidence shows a positive and significant relation between this EBC and firm value.

We also investigated the change in the marginal effect of EBC on firm value as a result of change in the percentage of independent directors in that firm. Our findings suggest that alignment of owners and management objectives, using EBC packages, is more evident in firms with higher participation of independent directors; that is, the positive effect on firm value increases as the percentage of independent directors increases.

\section{AUTHORS INFORMATION}

Abdallah M. Dah; Ph.D. - Abdallah Dah is a professor of economics at the Lebanese American University, Beirut, Lebanon. He earned a Ph.D. in Economics from the University of Colorado Boulder in 1988. His research areas include oil forecasting, energy consumption, price theory, tax incidence, and discrimination theory. Dr. Dah has published in journals such as Journal of Applied Energy, Journal of Energy and Development and International Journal of Business Research. E-mail: aadah@lau.edu.lb (Corresponding author)

Salaheddine S. Abosedra; Ph.D. - Dr. Abosedra is an economist whose areas of expertise include macroeconomic policies in oil based economies and energy economies. He conducted research at the IMF, held a Fulbright Fellow and taught at several universities in the Middle East and the USA. Recently, he spent two years as a Regional Advisor, Macroeconomics Policies at ESCWA, UN. His articles appeared in Applied Financial Economics, Applied Energy, and Energy Policy among other journals. He holds a Ph.D. in Economics from the University of Colorado. E-mail: salaheddin.abosedra@lau.edu.lb

Ghida F. Matar - Ghida Matar is currently an MBA student at the Lebanese American University (LAU). She has a BS Degree in Finance from the same university where she graduated ranking the first on School of Business. She worked as an auditor at PricewaterhouseCoopers and is currently employed at LAU as an assistant for the CEP Division's director as well as a Research Assistant in LAU's School of Business. E-mail: ghida.matar@lau.edu

\section{REFERENCES}

1. Bryan, S, and H. LeeSeok, and S. Lilien. (2000). CEO Stock-Based Compensation: An Empirical Analysis of Incentive-Intensity, Relative Mix, and Economic Determinants. The Journal of Business, 73 (4), pp. 661 693.

2. Byrd, J., Parrino, R., and Pritsch, G. (1998). Stockholder-Manager Conflicts and Firm Value. Financial Analyst Journal, 54 (3), pp. 14-30.

3. DeFusco, R., Johnson, R., Zorn, T. (1990). The Effect of Executive Stock Option Plans on Stockholders and Bondholders. Journal of Finance, 45(2), pp. 617-627.

4. Gerhart, B, and G. Milkovich. (1990). Organizational Differences in Managerial Compensation and Financial Performance. The Academy of Management Journal, 33 (4), pp. 663-691.

5. Hall, B. J., and Liebman, J. B. (1998). Are CEOs Really Paid Like Bureaucrats? Quarterly Journal of Economics 113 (August), pp. 653-91.

6. Hallak, W. (2011). The Effect of CEO Ownership and CEO Entrenchment on Firm Value. Lebanese American University https://ecommons.lau.edu.lb:8443/xmlui/bitstream/handle/10725/964/Waddah_Hallak Thesis.pdf?sequenc $\underline{\mathrm{e}=1}$

7. Hillegeist, S. and Fernando P. (2003). Stock Option Incentives and Firm Performance. http://ssrn.com/abstract $=480384$

8. Hojen,V. (2007). Equity-Based Compensation and Firm Performance, Aarhus University. http://pure.au.dk/portal-asb-student/files/1485/000155261-155261.pdf

9. Jensen, Michael C. and Kevin J. Murphy (1990). "CEO Incentives- It’s Not How Much You Pay, But How". Harvard Business Review, (3), pp.138-153.

10. Kaplan, S. (1989). Management Buyouts: Operating Improvements as a Source of Value. Manuscript. Chicago: Univ. Chicago. 
11. Kedia, S amdAbon M. (2002). Performance Impact of Employee Stock Options. http://ssrn.com/abstract $=304188$

12. McConnell, J., \&Servaes, H. (1990). Additional Evidence On Equity Ownership and Corporate Value. Journal of Financial Economics, 27, pp. 595-612.

13. Mehran, H. (1995). Executive Compensation Structure, Ownership, and Firm Performance. Journal of Financial Economics 38, pp. 163-84.

14. Murphy, K. J. (1998). Executive Compensation. In O. Ashenfelter and D. Card (eds.), Handbook of Labor Economics. Amsterdam: North-Holland.

15. Smith, A., (1990) Capital Ownership Structure and Performance: The Case of Management Buyouts. Journal of Financial Economics, 13, pp. 143-165.

16. Yermack, D. (1995). Do Corporations Award CEO Stock Options Effectively? Journal of FinancialEconomics, 39, pp. 237-269. 